\title{
Black Agency and Aesthetic Innovation in Sergio Giral's El otro Francisco
}

\author{
Philip Kaisary • Carleton University
}

\begin{abstract}
In 2013, Henry Louis Gates lamented the tradition of whitewashing and the passing over of slave stories which has become commonplace throughout cinematic history: "there have been all too few films that have captured, or even attempted to convey, the truth of the experience of slavery, from the slave's point of view" and even fewer "worthy of recognition." While it is true that there have been some high-profile films produced in the last decade - 12 Years a Slave, Django Unchained, and Birth of a Nation, among others - that have endeavored to represent slavery from the "slave's point of view," Gates' assessment remains largely apposite within the contexts of Hollywood and English-language productions. However, Afro-Latinx cinema and the history of post-revolutionary Cuban cinema in particular tells a very different story. To evidence this difference, this article will explore El otro Francisco, which was originally released in 1975, and is the first in a searing trilogy of films focused on slavery in Cuba in which perspectives of the enslaved are foregrounded and the traditional representation of slavery - which has to a great extent elided the rich history of slave resistance - is rigorously undermined.
\end{abstract}

$\mathrm{I}$ n 2013, Henry Louis Gates lamented the tradition of whitewashing and the passing over of slave stories which has become commonplace throughout cinematic history: "there have been all too few films that have captured, or even attempted to convey, the truth of the experience of slavery, from the slave's point of view" and even fewer "worthy of recognition." While it is true that there have been some high-profile examples produced in the last decade - Quentin Tarantino's Django Unchained (2012), Steve McQueen's 12 Years a Slave (2013), and Nate Parker's Birth of a Nation (2016), which defiantly challenges D.W. Griffith's notorious version of 1915, among others - Gates' assessment remains largely apposite within the contexts of Hollywood and English-language productions. However, Afro-Latinx cinema and the history of post-revolutionary Cuban cinema in particular tells a very different story and one in which a sustained attempt to represent slavery from the "slave's point of view" can be detected. To evidence this difference, this article will explore El otro Francisco, which was originally released in 1975, and is the first in a searing trilogy of films focused on slavery in Cuba in which perspectives of the enslaved are foregrounded. ${ }^{2}$ The effect of this foregrounding is to dramatically undermine the central tenets of the traditional cinematic, literary, and historiographical representation of slavery - which has to a great extent elided the rich history of slave resistance - and also typically includes such contradictory themes as black passivity, the construction of black males as quintessentially vengeful, violent, and sexually threatening to white women, and the romanticization and/or sanitization of slave society as essentially benign. "Fantastic product[s] of white anxiety" such as these, to borrow Aisha K. Finch's phrase, became, in different ways, important instruments in the maintenance and justification of slave societies and have profoundly marked the cinematic and cultural archives generated by Atlantic slavery. ${ }^{4}$ The director of El otro Francisco and the trilogy as a whole is Sergio Giral, a prominent Afro-Cuban-American filmmaker whose works have not received the same degree of critical attention as that of his more celebrated contemporary, Tomás Gutiérrez Alea (1928-1996), with whom Giral collaborated in the making of El otro Francisco. ${ }^{5}$ Born in Havana in 1937, Giral moved with his family to New York City towards the end of World War II so that his father could pursue a business opportunity. In New York City, Giral came of age in Greenwich Village at the height of the Beatnik generation; his "idols" were Allen Ginsberg and Jack Kerouac, 
and Jean-Paul Sartre was his "guru." ${ }^{\prime 6}$ However, inspired by the Cuban Revolution and eager to contribute to its early program of social justice, in 1961, Giral accepted an invitation to return to Cuba to work for the newly founded Instituto Cubano del Arte e Industria Cinematográficos ("ICAIC" - the Cuban Institute of Cinematographic Art and Industry). ${ }^{7}$

Giral's filmography spans feature films, 'shorts,' and documentaries, and reveals an adept ability for manipulating genre and reworking historical, literary, and cultural materials in order to offer commentary on the subjects of race and Afro-Cuban identity and heritage. For example, his 1986 film, Plácido, narrates the story of the Afro-Cuban poet, Gabriel de la Concepción Valdés - "Plácido" - who was executed following the ferociously suppressed black rebellion of 1843-44 known as "Conspiración de La Escalara" ("conspiracy of the ladder"), and who subsequently became an emotive folkloric symbol of resistance. ${ }^{8}$ Consider also Giral's much overlooked 1991 film, María Antonia, set in the pre-revolutionary 1950s in Cuba, which reworks Eugenio Hernández Espinosa's landmark 1965 play of the same name, and presents the figure of Mariá Antonia as a creolized Carmen. ${ }^{9}$ However, it is Giral's "slavery trilogy" for which he is most known, and although it has received limited critical attention within the North American and European academies, it is notable that El otro Francisco was recognized by the award of the FIPRESCI Prize at the 1975 Moscow Film Festival. ${ }^{10}$

Giral's trilogy as a whole, recovers the marginalized history of slave resistance in 19th century Cuba, asserts black subjectivity, and narrates a counter-history of slavery and abolition in Cuba. However, El otro Francisco in particular offers a socio-economic analysis of slavery and class struggle in Cuba by explicitly undermining and critically retelling the first anti-slavery novella in the Americas, Anselmo Suárez Romero's sentimental and sensationalist Francisco, which was written in $1838-39$, but was proscribed by Madrid and unpublished until 1880 . In this manner, in a docudrama format, Giral narrates a story of black subjectivity in relation to the history of black Cubans' struggle for freedom and equality. Black subjectivity is also at the fore in Rancheador, which offers a principled statement on the necessity of pre-emptive defensive violence in the context of the structural violence of 19th century Cuban slave society, while Maluala elaborates a story set in Cuba's palenques (communities of runaway slaves) in the mountains of the Sierra Maestra. Giral's trilogy is striking for its aesthetic and narratological innovation: for example, El otro Francisco employs Brechtian techniques, including freeze frames and the use of a critical, didactic narrator who directly addresses the viewers. By this didactic exposition, the film serves as a rigorous historical and sociological examination of the ideological thrust of Romero's novella. By way of contrast - and in order to demonstrate the range of Giral's filmic aesthetics - it should be noted that the second and third films in the trilogy employ radically different approaches for foregrounding black agency. For example, Rancheador, the second film in the trilogy, conjures in filmic language the co-existence of the past and the contemporary, the rational and the magical, while Maluala, the final installment in the trilogy, can more easily be interpreted as an "adventure film." Nevertheless, despite their varied aesthetic registers, the trilogy as a whole is unified by the foregrounding of black agency and an insistence on the formative role slavery has played in the creation of the modern self, as well as Cuban and global modernity. As such, Giral's trilogy elaborates a representation of Atlantic slavery not as aberrational, but as fundamental to a rapidly expanding capitalist world-system, while evoking a radical conception of anti-capitalist freedom borne of the highly contingent experience of the African slave trade and the plantation system in the Americas.

\section{El otro Francisco: The Prologue}

El otro Francisco, shot in black and white, opens in dramatic fashion: we see the eponymous Francisco [Fig. 1], an enslaved black man, and Dorotea, an enslaved mulata, gazing longingly at each other before they rush towards each other and embrace passionately in a riverside forest clearing. Immediately, it is apparent that Francisco and Dorotea's emotional anguish is an instance of the cruelties inflicted by slavery on enslaved families longing for romantic love. Dorotea is unable to hold back her tears as she reveals to Francisco that she allowed their master, Ricardo, to rape her in order that Francisco be saved. Wracked by guilt and punished by patriarchal slave society, Dorotea declares that she did everything for Francisco but that she now must travel to Havana with their mistress, Ricardo's mother, and that she cannot bear to see Francisco ever again. This news devastates Francisco, and seeing this, Dorotea, unable to bear the pain, rushes away with tears streaming down her face. Francisco, alone with his feelings of despair in the forest, runs between trees and lashes out with his limbs at the tall grasses and tree branches; he eventually collapses to the ground in agony and, with dramatic orchestral mood music in the background, Francisco resolves to hang himself. Some days later, drawn by the buzzards that were circling a tree, the master and the plantation overseer discover Francisco's body. Francisco's suicide is thus presented as an instance of death as a form of freedom from pain and suffering - a well-rehearsed trope in black diasporic cultural production. ${ }^{11}$ When Dorotea learns of Francisco's death - the news reaches her via a letter from Ricardo to his mother, who then relays the news to Dorotea - she is overcome with grief, "wastes away" and dies only a few years later.

This narrative of enslaved lovers whose relationship is thwarted and their fate doomed by the behaviour of a depraved master is one that would be familiar to readers 
of sentimental anti-slavery writing. ${ }^{12}$ And indeed, at this juncture the film reveals that this is precisely what this opening has been: the film cuts to a well-to-do and fashionable Havana literary salon where the novelist Anselmo Suárez Romero is reading from his freshly completed manuscript, Francisco. The narrator then declares that the film will proceed as a Brechtian investigation into the ideas presented by, and critical limitations of, this celebrated sentimental anti-slavery novella. The narrator informs the viewer that Domingo del Monte, a bourgeois intellectual, social reformer, and the host of the literary salon, had suggested to Suárez Romero "a novel to lay bare the plight of the slaves." Suárez Romero's reading is met with adulation, applause, and a standing ovation. He is warmly embraced by a number of men present at the salon, including del Monte, and he receives the praise of a number of women; the appearance of these finely dressed and fastidiously coiffured participants in del Monte's literary salon could not form a more striking contrast with the simple and worn attire of Francisco and Dorotea. Champagne is served on silver trays and the narrator informs the viewer that the novel's overwhelmingly positive reception in this circle leaves no doubt that it satisfied the demands of these bourgeois reformist ideologues. At this juncture, Giral leaves it to the viewer to discern the hypocrisies of this well-meaning bourgeois collective, but the narrator explicitly poses the fundamental question that will animate the rest of Giral's film: "Is a real view of the slave provided by the author through his character, Francisco? Let us see if the rejoicing over the novel was justified or if it failed to show un otro Francisco." In this critical, Brechtian fashion, Giral begins his inquiry, explicitly framing the film as sociological and materialist whilst also drawing attention to the sociopolitical context of Cuba's literary history via its focus on Romero's original novella. Notably, this ideological thrust can be identified as one that accords with the ICAIC's commitment to the critical examination of Cuban history and culture, and to the Revolution's cultural goals. After this prologue, the opening credits appear and, in an expression of pan-Caribbean revolutionary solidarity, "The Haiti Group" (Cuba's Haitian residents) are thanked, and this linking of Cuba's national history to Haiti's anti-slavery revolutionary heritage has the effect of making visible the closeness of Cuba and Haiti. The histories of slavery and abolition in Cuba and Haiti superficially appear radically different, since Cuba was one of the last territories in the Americas to abolish slavery (in 1886) and Haiti the first to do so as a result of the Haitian Revolution of 17911804. However, Giral's film draws the histories of these two Caribbean nations closer together, emphasizing revolutionary affinities. The effect of minimizing the differences between Haiti - memorably dubbed by Aimé Césaire as "the most African of the Antilles"13 - and Cuba is to emphasize that black agency in resistance in Haiti was not singular or exceptional, and that Cuba too is "African". Giral's film thereby, from the outset, unsettles the identification of Cuba as an exclusively or predominantly Latino or mulato society rather than as a black diasporic site, and Giral's granting prominence of place to Cuba's Haiti group in the opening credits is also consistent with the film's situating of slavery in Cuba in its wider Caribbean and global contexts, rather than in its narrower Spanish colonial context. This comparative perspective encourages an understanding of slavery and slave resistance in transnational terms, and makes clear that Cuba and Haiti should both be understood as locations of historical black agency and that more binds these two territories together than drives them apart.

\section{Ricardo's Plantation}

With the sentimentality of Suárez Romero's version established, the film proceeds to narrate the story of 'the other' Francisco. Giral's script brings the viewer up to speed quickly: through a conversation between Ricardo and the plantation overseer, we learn that Dorotea is Ricardo's mother's favourite slave and that she serves her as a seamstress and her maid. Ricardo has just discovered that Dorotea is pregnant with Francisco's child and this provokes Ricardo to instruct his overseer to mete out abominably cruel tortures: sadistic whippings and the rubbing of urine, alcohol, salt, and gunpowder into Francisco's wounds. This opening recalls the narratorial approach of the unorthodox black British Marxist writer and political activist C. L. R. James, in the opening chapter to his classic history of the Haitian revolution, The Black Jacobins. ${ }^{14}$ There, in a chapter accurately and ironically titled, "The Property," James documented in a matter of fact style, the innumerable, inventive, and cruel means and methods of slave torture. Wanton and barbaric, this catalogue of tortures serves as indisputable evidence that slavery was founded on an intricate system of terror, and that apologists for empire cannot explain or excuse slavery as benign, paternalistic, or civilizing. The impact of this strategy in El otro Francisco is highly comparable: without subjecting the viewer to gratuitous horrors, Giral unequivocally conveys the physical traumas and coercive violence on which slavery depended, without losing sight of the structural violence endemic to slavery.

The camera then cuts to Francisco among a group of slaves cutting sugar cane in the fields while singing a work song, when, suddenly, Francisco collapses from exhaustion later the overseer will claim that he "staged a faint" in order to escape working - such everyday forms of resistance being a commonplace frustration for the planter class. However, Francisco's queasiness and exhaustion are clearly conveyed. This unequivocal representation of the mundane harshness of slave labour is worthy of comment since it is either elided or romanticized in so many other films focused on slavery. Moreover, this elision and/or romanticization has occurred 
for many years - from the 'Golden Age' of Hollywood to the twenty-first century - and in films of widely varying aesthetic tenor and ideological intent. Consider, for example, the 1939 classic, Gone with the Wind and also Steve McQueen's 12 Years a Slave..$^{15}$ Following this scene, the narrator interjects to provide information on both Francisco and Dorotea, and their roles on the plantation. We learn that Francisco was taken from Africa at the age of 10; he is a house slave who stands out for his excellence, his malleability, loyalty, and good nature. He is, the narrator proclaims, "free of vice." Then the narrator formally introduces Dorotea: we learn that her mother nursed the young Ricardo, and that her beauty, innate goodness, and kindness made her seem to Francisco, "an ideal companion to lighten his slave's burden." This phrase recalls a notion that was in circulation in the wake of the Haitian Revolution: that the companionship and physical intimacy that female slaves could provide to male slaves would decrease the probability of slave uprisings. Accompanying this description are startling beautiful portrait shots of Dorotea and Francisco that are perhaps indications of Giral's early training as a painter. [Fig. 2] The narrator continues, informing the viewer that Francisco had requested his mistress's permission to marry Dorotea but that such permission was refused, a historically unlikely refusal since marriage was encouraged for reproductive and moral purposes. We then learn that Francisco and Dorotea embarked on a clandestine affair for two years, at the end of which Dorotea became pregnant. In response to this flouting of her orders, the mistress commands the whipping of Francisco and, contrary to the slavery codes which stipulated that slave owners should keep slave families together, sends Dorotea to a French mistress in Havana where she is to work as a house slave assigned to the laundry. Throughout this narration, the romantic aspect of this story is accentuated by soft flute music, but then, the picture freezes and the music abruptly stops: Giral rouses the viewers from the dreamy, uncritical state into which he has strived to inculcate them. Suddenly, the viewer becomes aware that $\mathrm{s} /$ he has been manipulated and that the intense drama of this romance, the soft music, and the beautiful portraits of these star-crossed lovers had lulled them into accepting an extremely limited understanding of the realities of slave life. As Francisco assists Dorotea in climbing into an ornately decorated carriage, presumably to be taken away to her new mistress, the Brechtian narrator asserts: "Francisco and Dorotea act in keeping with the novel's romantic selling point; but the 'real facts' of slave life and love were different." During the narrator's voiceover, Giral proceeds to show us - in brief self-contained episodes, and by further more detailed description and analysis from the narrator - how slave life differed from Romero's depiction. The picture unfreezes and cuts to a scene of a black slave woman on a riverbank being assaulted by a white man - the lack of sound estranges the viewer from the scene and renders it more shocking. Meanwhile, the narrator continues, explaining that slave relationships and slaves' sexual lives were profoundly circumscribed and limited by their condition as slaves: there were far fewer slave women than there were slave men, and the sexual abuse of slave women by the planter class was rife. ${ }^{16}$ Then, immediately following the provision of more sociological information from the narrator, is a scene that shows a slave woman preparing a homemade remedy that she drinks to abort a pregnancy; save for tribal sounding music that evokes Africa - drums and flute - the scene takes place in silence. The effect is to shock without numbing the viewer's capacity to understand as well as to feel. The scene concludes with the enslaved, pregnant woman collapsed on the ground, convulsing with agonizing uterine contractions. It is a powerful depiction of female agency that recalls both Toni Morrison's Beloved (which would appear in print some twelve years after the release of El otro Francisco) and Cuba's decriminalization of abortion in 1965, which lifted the intensive bureaucratic administrative processes that had the effect of criminalizing women's reproductive decision-making. ${ }^{17}$ We see the slave woman asserting control over her own body and fate, yet the trauma and pain of the abortion is communicated powerfully. Yet, this is anything but an emotionally manipulative and theatrical staging of slave suffering designed to arouse mere sympathy (such an approach is a common one in abolitionist literature and is also the approach emphatically taken in McQueen's 12 Years a Slave). ${ }^{18}$ Instead, in Giral's hands, the suffering of this enslaved pregnant woman is used to make the viewer aware of multiple levels of culpability: the institution of slavery itself is indicted and held responsible for the slave woman's act, since she is aborting the fetus in order to avoid bringing a new life into the conditions of slavery. But we can presume - given the earlier sequence showing the assault on the riverbank - that the slave woman was raped and, therefore, the individual rapist's culpability is not absolved. Giral thus subtly reveals the systemic horrors of slavery without losing sight of individual suffering, nor the culpability of individual members of the planter class, their overseers, and plantation managers for their actions.

\section{Another Ricardo}

Dorotea's resistance of Ricardo's advances drives Ricardo into a frustrated frenzy. This culminates when, in a fury, Ricardo shoves, pushes, and slaps Dorotea before giving her an ultimatum that unless she submits to him, he will ensure that Francisco is tortured to death, this threat revealing that Ricardo is willing to delude himself into believing that an absence of resistance from Dorotea would signify desire. As Dorotea continues to refuse her master's advances, true to his word, Ricardo ensures that Francisco is treated ever more severely with frequent whippings and punishments. When one day Dorotea accompanies her mistress 
to the plantation infirmary and discovers Francisco lying prostrate in agony from his prolonged tortures, Dorotea is overcome with grief and guilt. In the following scene, she approaches Ricardo and allows herself to be raped by him to spare Francisco further agony. In the midst of the rape scene, Giral freezes the frame and there is a Brechtian interjection from the narrator: "In the novel, Ricardo is moved only by his passions, but was that the reason he set out to cause pain to Francisco and Dorotea? Millowners of the times had other motivations. There's another Ricardo [un otro Ricardo] whom the author does not show us." We can here identify another commonality with C.L.R. James' Black Jacobins; Giral's project can in part be understood as an attempt to render in filmic language the following argument that James so strikingly articulated: "There were good and bad Governors, good and bad Intendants, as there were good and bad slave-owners. But this was a matter of pure chance. It was the system that was bad."19 Giral thereby problematizes the focus on individuals as an explanation for the injustice of slavery and exposes the limitations of Suárez Romero's approach.

So, who is this 'other' Ricardo? In the words of the narrator, he is, like other members of the planter class, "a slave lord," entering modern capitalism with a "deep class consciousness" and a keen sense of the possibilities afforded by technological advances. The "Ricardo" Giral presents us with is a capable manager of a business, one able to enter into dialogue with engineers, economists, and priests, and produce a cogent defense of the political economy of slavebased sugar production premised simply on what he regards as the absolute necessity of increasing productivity. So, as Ricardo strolls through his plantation with other members of the planter class, he is quite at ease discussing costs and savings, and entering into debates over the merits of taking advantage of technological advances. ${ }^{20}$ It thus comes as little surprise that Ricardo is visibly excited by the prospect of replacing his ox-driven mill with an English Fawcett \& Preston steam driven mill when it is presented to him by an English company agent. This scene, which clearly influenced Tomás Gutiérrez Alea's presentation of a similar scene in La última cena, ${ }^{21}$ demonstrates that technological advances serve merely to intensify the exploitation of the slave class while also revealing the transnational dimensions of the Atlantic slave-system. Here Giral is at pains to inform the viewer that just as Suárez Romero's production of a sentimental anti-slavery romance fails to communicate of what Atlantic slavery was an instance, the emphasis on British abolitionism in the early 19th century as philanthropically motivated fails to understand England's economic interests in breaking down the colonial mercantile system in order to open up more markets for English businesses. ${ }^{22}$ Thus, with great clarity and concision - the point is not labored and the running time of El otro Francisco is a mere 100 minutes - Giral presents his viewers with an argument that the deep causal explanation for the misery and abomination of slavery is not fundamentally the lust and violence of individual masters - so called "bad apples" - but slavery's essential role in an international economy of trade and exchange in which the beneficiaries of slavery are sometimes hidden by complex production and commodity chains, and sometimes the beneficiaries of slavery hail from a jurisdiction such as England that proclaims itself to be a crusader for abolition. Thus, far from being an outmoded relic of a feudal order, slave labor, Giral shows us, was an integral part of Atlantic capitalism that generated extraordinary profits throughout Europe and the Americas. The ideological thrust of Giral's vision must, therefore, be situated alongside not only the works of his fellow Cuban filmmakers at the ICAIC - especially Tomás Gutiérrez Alea, and specifically La última cena - but also alongside the writings of C. L. R. James, Eric Williams, W. E. B. Du Bois, and Walter Rodney whose works collectively constitute a radical Black intellectual tradition in which slavery is rigorously treated as a system of capital accumulation. ${ }^{23}$

Giral's elaboration of this 'other' Ricardo continues in a dinner scene at which there is some spirited discussion among members of the planter class as to whether advancing technology will eventually render slave labor entirely unnecessary. The notion of paying the blacks for their labor is discussed, and it is argued whether it would be more efficient and hence profitable: strikingly, ethics and consideration of the slaves' well-being have no place in this discussion, although some of this is perhaps explained by the gap between the legal discourse surrounding slavery and the actual practices of slavery. The situation of the ex-slaves in the English colonies is considered with the conversation revolving around one question only: which is the more efficient mode of labour exploitation and of extracting surplus value from the labour force - the formal 'freedom' that 'free' labour grants is entirely incidental to the debate. It is also noteworthy that the lingering aftermath of the Haitian Revolution makes itself felt during this scene: the lone advocate for 'free labour' and 'economic progress' is rounded on by the others, all of whom fear that such 'progress' will usher in the end of their privileged positions as slave lords in Cuba. The specter of Haiti haunts them and the example of the once "flourishing" colony of Saint Domingue that has become a fearful "republic of blacks" is used to put a definitive end to all talk of free labour and abolition as conduits to progress. ${ }^{24}$

\section{Black Agency}

Following the dinner scene, Giral provides another Brechtian direct address from the narrator. Francisco's narrative is about to be shown in a dramatically new light, and the narrator informs the viewer that, true to his word, Ricardo halted Francisco's tortures. The film then replays, without the sound, the scenes presented earlier in the 
prologue: Francisco and Dorotea's passionate embrace, Dorotea's anguished revelation of how she has gone to bed with the master to save Francisco, and Francisco's consequent despair and suicide. The narrator then boldly asks us to consider - as a means of opening the film's most explicit examination of the theme of black agency and resistance - whether "a typical slave of the time" would have reacted as Francisco did. The film then cuts to a scene in which Suárez Romero is being interviewed on the subject of his novella. In response to the question, is Francisco "a typical slave," Romero's response is striking: "Absolutely not typical: how could a slave suffer as much as Francisco and not be rebellious? He's a freak, a singular exception who helps me denounce the horrors of slavery by contrast with the cruelty of the masters." In sum, according to Giral's Romero, Francisco has a remarkable "mildness and Christian resignation so hard to find in slavery." Romero's words reveal Francisco to be a rhetorical device and the mirror image of the lusty, sadistic Ricardo: Francisco's goodness forms a contrast with the cruelty of the slave owners and overseers. The veracity of all this, Giral will challenge. Having used Romero's own words to establish the historical improbability of the virtuous Francisco's docility, the narrator opens the next segment of El otro Francisco with the following words:

Maybe behind the good intentions of Suárez Romero and other sincere anti-slavers there moved class interests that pursued with the ideal image of the slave, not only an improvement in the owners' conduct. Perhaps the real aims of the capitalist ideologists and the British Empire in suppressing the slave trade weren't only philanthropic. Let's take the novella as the starting point to look at the real situation of slavery and the true picture of a slave mill of the times.

"The real situation of slavery" is immediately presented as one of unending resistance on the part of the slaves, a critique that first emerged in the late 1930 and was then taken up with gusto by revisionist historians in the 1950 on and $60{ }^{25}$ The camera cuts to a new scene: it is Ricardo's plantation again, shot from a camera positioned high above the plantation buildings. The camera then focuses on a would-be maroon named Crispín who has been captured, bound in ropes, and is being returned by a rancheador on horseback to the plantation overseer for punishment. Unlike the meek Francisco, the slave's face is a portrait of simmering indignation and defiance. He is placed in the stocks but then released to cut cane the following day. During a brief rest break that day, Crispin is eager to spread the word among the enslaved, and he tries to persuade Francisco that resistance is their duty and will in the end be fruitful. Though unsuccessful in escaping, Crispin's determination to break the chains of his bondage is entirely undiminished. Crispin talks rousingly of Guinea as a place just beyond the mountains, and of a place where blacks are free, equal, able to marry, raise children, and live peacefully in the absence of masters and overseers. When Francisco mocks him, retorting that this idyllic place is as fictional as the myth that Guinea can be reached in death, Crispin urges his companion to come to a meeting that evening where plans for a rebellion will be laid. During the slaves' nighttime meeting, the film's ambience and aesthetic register embarks in a dramatically new direction: numerous slave voices are heard, African drumming and dancing takes place, and a current of insubordination and refusal is unmistakeable. Now Suárez Romero's sentimental love-triangle novella will be juxtaposed with a very different account of slavery, one in which black agency and resistance is central, an ever-present threat, and animated by a vision of not just emancipation but also of social justice.

At the meeting there is song, dance, ritual, and speeches - an intricate and rich living culture is on display. While Ricardo and his fellow planters considered the slaves only in terms of their labour value, at the meeting they are individualized, demonstrate a capacity for creativity, solidarity, and an awareness of occurrences of slave resistance from beyond Cuba's borders. At the meeting, the chief orator exclaims to his enrapt companions: "Deh's a land dat the blacks call Haiti. where we's free already, de massas gwan run away over de ashes o' dey houses." It is a powerful representation of the impact of the Haitian Revolution spreading across the region, transcending linguistic barriers and inspiring enslaved populations throughout the Americas. ${ }^{26}$ As such, it is a further attempt by Giral to tease out the influence of Haiti's revolutionary history on a praxis of Cuban anti-slavery resistance. The following night, there is a further meeting at which there is more singing, drumming, and dancing, but this time it becomes apparent that the ringleaders have carefully planned an uprising: a vanguard group of slave rebels have set the plantation buildings alight, and during the ensuing chaos, they escape. Yet, in an intense sequence, the next day rancheadors on horseback with hunting dogs pursue and capture two of the runaways in a scene set to more tribal, percussion-based music that evokes Africa. Slave society, it appears from this representation, will never be settled and calm, and should be understood as a constant struggle against repression.

Then, the narrator interjects to explain why this tradition of Cuban black resistance was not a subject of interest to Suárez Romero, Del Monte, and the island's bourgeois anti-slavery reformers: the dependency on free blacks, and even some poor whites, was so great that it was feared that news of black resistance might destabilize the colony's social hierarchy. To further explain the domestic complexities of anti-slavery politics in Cuba at this time, Giral then stages a brief conversation between Del Monte and Richard Madden, an Irish doctor and ardent abolitionist who, as British consul in Havana, was, inter alia, tasked with reporting on observance of the Anglo-Spanish Treaty of Madrid of 1817 which 
had granted the British navy the right to inspect Spanish ships suspected of slaving. ${ }^{27}$ In their conversation, Del Monte explains to Madden that there was no appetite in Madrid for abolishing slavery in Cuba (or anywhere else in the Spanish Empire), and that among the colony's reformist population, a fear of the potential for black insurrection was holding back the cause of independence. Little wonder then that Suárez Romero elected to focus the attention of his anti-slavery novella on romantic themes and a Christ-like, meek, male slave protagonist rather than seek to recuperate the tradition of slave resistance in the colony. Following this conversation, Giral conveys the tragic reality of almost all slave rebellions: Crispin has been captured and is dead, and the overseer mutilates the rebel's dead body "so that he has no interest in coming back to life" - a barbaric act and comment that suggests the attempt to torture and immiserate the slave rebel in any afterlife, thereby thwarting any paradisial freedom to be found in death.

Yet Crispin's capture and murder are far from the end of the representation of black resistance in El otro Francisco. In the remaining 25 minutes, Giral's unwavering focus is on slave resistance in order to definitively demonstrate the limitations of Suárez Romero's novella - and, from Giral's perspective in the mid-1970s in Cuba, the profound mistake of turning the history of abolition into one centered on morality and sentiment. While Ricardo is raping Dorotea, the slaves begin to put a carefully planned rebellion into action, and this time Francisco is a key conspirator. The insurrection begins when Francisco sabotages the sugar mill grinder by thrusting a machete blade into the cogs; the mill is badly damaged and no longer functional - it will take a few days to fix. Ricardo hurries to examine the scene and orders the overseer to identify the slave responsible; he singles out Francisco who is whipped savagely. Giral presents this torture and the context of endless slave resistance as crucial missing pieces in Francisco's story as presented by Suárez Romero. The narrator describes these omissions in the novella as "censorship" and asserts that thwarted romantic love is an insufficient explanation for his suicide. Moreover, the narrator seeks to persuade the viewer that Francisco's suicide should be regarded as a form of resistance: "Suicide was one form of slave resistance. But there were others." ${ }^{28}$ These words are the prelude to the dramatic finale of $E l$ otro Francisco: the drum and percussion music resumes, and another slave uprising begins, and this time there are many rebels. [Fig. 3] The rebels set the cane fields alight and the rebellion quickly gains momentum: the overseer is assaulted and strangled. The narrator then establishes that an insurrection such as this would not have been an isolated event:

Long before and then after the Suárez Romero novella, a wave of uprisings shook plantations across Cuba. 1812: uprisings in mills at Puerto Principe, Holguin, Bayano Trinidad, and Havana led by Josè
Antonio Aponte; 1825: rebellions at mills and ranches in Matanzas, 24 estates sacked and burned, 15 whites and 43 blacks killed; 1830: uprising at a coffee plantation near Havana; 1835: uprising at the Carolina Mill and a coffee plantation; 1837: insurrection in Manzanillo and Trinidad mills; 1842: uprising at the Loreto Mill near Havana and a coffee estate in Lagunillas; 1843, January 27 and 28: uprising in the Alcancia mill in Matanzas, followed by a coffee estate, and a ranch, and four other sugar mills, plus the builders of the Cardenas-Jaruco railroad; November 5 of the same year: uprising at the Triunvirato mill in Matanzas that spread to the slaves at four other mills.

Immediately following these words of the narrator's, there are brief, appalling scenes of retaliatory punishments and executions committed by the planter class. But these scenes are immediately countered with further scenes of slave resistance before Giral cuts to a final panoramic shot of the lush Cuban hills: a landscape in which, as Giral states in the film's last title card, many more atrocities would come to pass before the eventual liberation of the Cuban nation. 


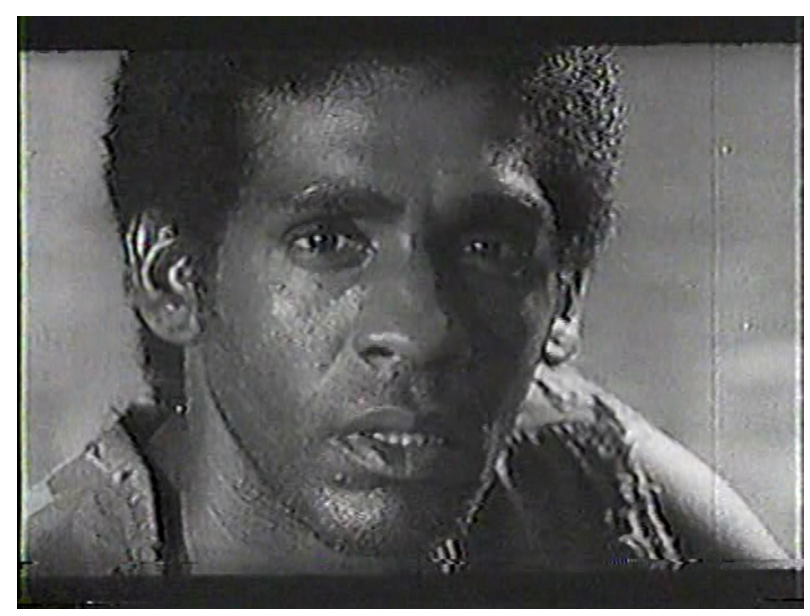

Figure 1

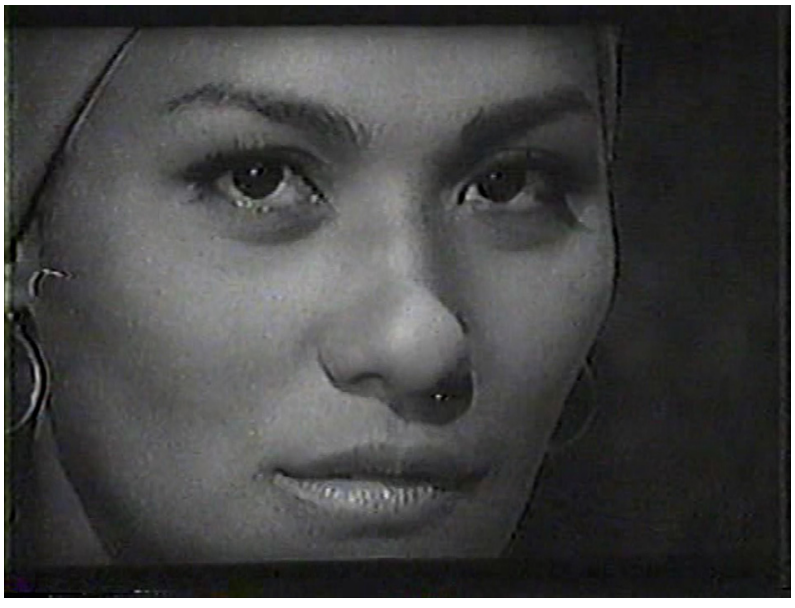

Figure 2

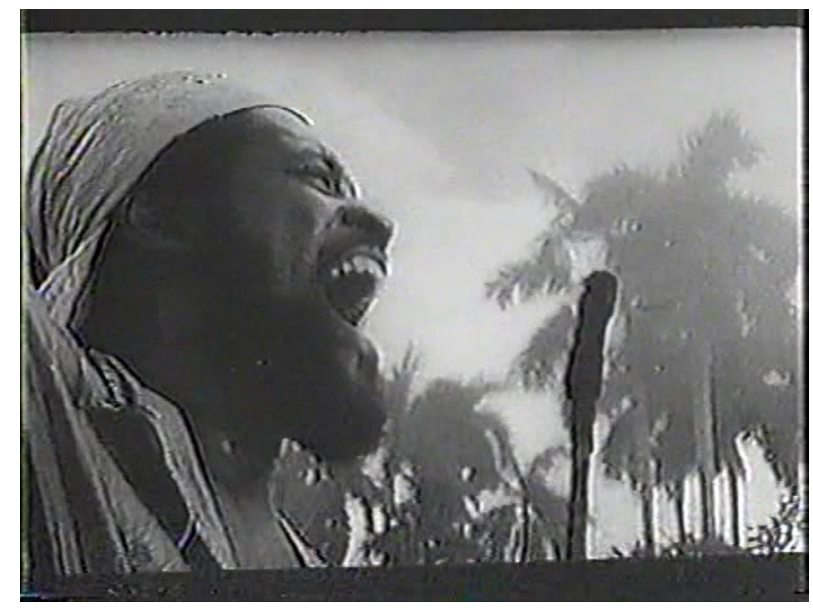

Figure 3 


\section{NOTES}

1. Henry Louis Gates, Jr. "Utter Darkness," 12 Years a Slave: Production Notes, (Fox Searchlights Pictures, 2013). Available at: www.samdb.co.za/ filmproductionnotes/1760.

2. The second and third films in the trilogy are: Rancheador (1976) and Maluala (1979).

3. Among the most notorious and racist examples, consider: D.W. Griffith's Birth of a Nation (1915), and the novel on which it was based, Thomas Dixon Jr.'s The Clansmen: A Historical Romance of the Ku Klux Klan (1905, rpt. Lexington: University Press of Kentucky, 1970). However, also consider Margaret Mitchell's Gone with Wind (London: Macmillan, 1936) and the film adaptation it generated, Victor Fleming (dir.), Gone with the Wind (Selznick International Pictures / MGM, 1939), both of which appear to remain beloved and reviled in equal measure.

4. Aisha K. Finch, Rethinking Slave Rebellion in Cuba: La Escalera and the Insurgencies of 1841-1844 (University of North Carolina Press, 2015), 183.

5. Cuban directors Héctor Veitia and Julio García Espinosa are also listed as collaborators. In addition, Giral cast many of the same actors that would appear the following year in Alea's La última cena (“The Last Supper”); Tomás Gutiérrez Alea, dir. La última cena (Instituto Cubano del Arte e Industria Cinematográficos, 1976).

6. Sergio Giral interview with Pablo Velez, "Close-Up on the Background: A Conversation with Sergio Giral, The Father of Afro-Cuban Cinema," Abernathy Magazine, https://abernathymagazine.com/sergio-giral/. Accessed September 25, 2019.

7. Thirty years later, in 1991, Giral would once again leave Cuba. In a recent interview, Giral explained: “The romantic ideals that had brought me to the island as a young man had slowly evaporated over time. I found the country's double standards perpetuated the racism, social inequality, and political repression that it pretended to cure." Ibid.

8. Sergio Giral (dir.), Plácido (ICIAC, 1986). The escalera, the name by which the rebellion became known, refers to a simple wooden ladder to which captured rebels were tied and then tortured. See: Aisha K. Finch, Rethinking Slave Rebellion in Cuba: La Escalera and the Insurgencies of 1841-1844 (University of North Carolina Press, 2015).
9. Sergio Giral (dir.), María Antonia, (ICIAC, 1991). For commentary, see: Nadia Sophia Sanko, “Creolizing Carmen: Reading Performance in María Antonia, Cuba's Overlooked Carmen Adaptation," Camera Obscura, Vol. 27, No. 1 (2012): 157-91; Leo Cabranes-Grant, "Possession, Gender and Performance in Revolutionary Cuba: Eugenio Hernández Espinosa's María Antonia,” Theatre Research International, Vol. 35, No. 2, (2010): 126-38.

10. FIPRESCI: Fédération Internationale de la Presse Cinématographique [International Federation of Film Critics]. See: http://fipresci.org/awards/1975.

11. For a detailed examination of the cultural and political significance of death in the black diasporic Atlantic world, see: Vincent Brown, The Reaper's Garden: Death and Power in the World of Atlantic Slavery (Harvard University Press, 2010).

12. For example, this trope is also prominent in Steve McQueen's adaptation of Solomon Northup's narrative, Twelve Years a Slave: Steve McQueen (dir.) 12 Years A Slave (Fox Searchlight, 2013). For analysis see: Philip Kaisary, "The Slave Narrative and Filmic Aesthetics:

13. Steve McQueen, Solomon Northup, and Colonial Violence," MELUS, (Vol.42, No. 2, Summer 2017): 94-114.

14. “An Interview with Aimé Césaire Conducted by René Depestre," in Discourse on Colonialism by Aimé Césaire, trans. Joan Pinkham, (New York: Monthly Review Press, 2000): 90 .

15. C. L. R. James, The Black Jacobins [2nd ed. rev. 1963] (New York: Vintage, 1989).

16. Victor Fleming (dir.), Gone with the Wind, (MGM, 1939); Steve McQueen (dir.), 12 Years a Slave, (Fox Searchlight, 2013). For analysis of the representation of labour in 12 Years a Slave, see: Philip Kaisary, "The Slave Narrative and Filmic Aesthetics: Steve McQueen, Solomon Northup, and Colonial Violence.” MELUS: Multi-Ethnic Literature of the United States. Vol. 42, No. 2 (2017): 94-114, 106.

17. Finch, Rethinking Slave Rebellion in Cuba, p.40. Moreover, Finch notes that the sporadic available accounts, and the population imbalance along gender lines, also suggest that "black women also had to be vigilant about sexual exploitation from black men.” (41) 
18. Cuba became the first Latin American country to legalize abortion in 1965 although in practice access to abortion remained limited until 1972. See: Elise Andaya, Conceiving Cuba: Reproduction, Women, and the State in the Post-Soviet Era (Rutgers University Press, 2014): 42-3.

19. For analysis of the harrowing - and brutalizing - depictions of slave torture in McQueen's 12 Years a Slave, see: Kaisary, "The Slave Narrative and Filmic Aesthetics," MELUS. Vol. 42, No. 2 (2017): 94-114, 106-108.

20. C. L. R. James, The Black Jacobins, 35.

21. This glimpse of slavery as a thoroughly modern system that is here offered by Giral is elaborated much more fully in Manuel Moreno Fraginals, The Sugar Mill: The Socioeconomic Complex of Sugar in Cuba, 1760-1860, trans. Cedric Belfrage, (New York \& London: Monthly Review Press, 1976).

22. For analysis see: Philip Kaisary, "The Haitian Revolution and Tomás Gutiérrez Alea's La última cena," in Racialized Visions: Haiti and the Hispanic Caribbean ed. Vanessa K. Valdés, (SUNY University Press, forthcoming).

23. This British strategy drives the narrative in Gillo Pontecorvo's cult classic film about slave revolution and Machiaevellian colonial manipulation in the 19th century Caribbean. See: Gillo Pontecorvo (dir.), Quemada! / Burn! (Alberto Grimaldi, Produzioni Europee Associati, 1969).

24. For consideration of this radical tradition in light of the re-emergence of slavery and capitalism as a flourishing academic subfield, see: Peter James Hudson, "The Racist Dawn of Capitalism: Unearthing the Economy of Bondage," Boston Review, March 14, 2016. Available at: http://bostonreview.net/books-ideas/ peter-james-hudson-slavery-capitalism.
25. For an analysis of the retrenchment and intensification of slavery in Cuba as a consequence of the Haitian Revolution, see: Ada Ferrer, Freedom's Mirror: Cuba and Haiti in the Age of Revolution, (New York: Cambridge University Press, 2014). Also see: Dolores GonzálezRipoll Consuelo Naranjo, Ada Ferrer, Gloria García, and Josef Opatrny, El rumor de Haití en Cuba: temor, raza y rebeldía, 1789-1844, (Madrid, 2004).

26. The earliest examples of this historiographical tradition are: Hebert Aptheker, American Negro Slave Revolts (Columbia University Press, 1943) and the preceding journal article: Herbert Aptheker, "American Negro Slave Revolts," Science \& Society, (Vol. 1, No. 4, 1937): 512-538. Also see: C.L.R. James, A History of Negro Revolt (Independent Labour Party, 1938), revised and republished in 1969 as: A History of Pan-African Revolt (Drum and Spear Press, 1969).

27. For an account of the transnational networks that transmitted news of the Haitian Revolution and other insurrections and mutinies in this period, see: Julius S. Scott, The Common Wind: Afro-American Currents in the Age of the Haitian Revolution (Verso: 2018).

28. Gott, Cuba: A New History, 60-61. Madden's memoranda of his visit to Cuba was published as: Richard Madden, The Island of Cuba: Its Resources, Progress, and Prospects, Considered in Relation especially to the Influence of its Prosperity on the Interests of the British West India Colonies, (London, C. Gilpin, 1849).

29. For an examination of suicide as a form of Cuban slave resistance see: Louis A. Pérez Jr., To Die in Cuba: Suicide and Society, (University of North Carolina Press, 2012): 25-64.

\section{WORKS CITED}

Alea, Tomás Gutiérrez, director. La última cena. Instituto Cubano del Arte e Industria Cinematográficos, 1976.

Andaya, Elise. Conceiving Cuba: Reproduction, Women, and the State in the Post-Soviet Era. Rutgers University Press, 2014.

Aptheker, Hebert. American Negro Slave Revolts. Columbia University Press, 1943.

Aptheker, Herbert. "American Negro Slave Revolts.” Science \& Society, vol. 1, no. 4, 1937, pp. 512-538.

Brown, Vincent. The Reaper's Garden: Death and Power in the World of Atlantic Slavery. Harvard University Press, 2010.
Cabranes-Grant, Leo. "Possession, Gender and Performance in Revolutionary Cuba: Eugenio Hernández Espinosa's María Antonia.” Theatre Research International, vol. 35, no. 2, 2010, pp. 126-38.

Césaire, Aimé. Interview with René Depestre. Dis $\neg$ course on Colonialism by Aimé Césaire, translated by Joan Pinkham, Monthly Review Press, 2000, pp. 79-94.

Dixon, Thomas, Jr. The Clansmen: A Historical Romance of the Ku Klux Klan. 1905. Lexington: University Press of Kentucky, 1970.

Ferrer, Ada. Freedom's Mirror: Cuba and Haiti in the Age of Revolution, Cambridge University Press, 2014. 
Finch, Aisha K. Rethinking Slave Rebellion in Cuba: La Escalera and the Insurgencies of 1841-1844. University of North Carolina Press, 2015.

Fleming, Victor, director. Gone with the Wind. Selznick International Pictures / MGM, 1939.

Fraginals, Manuel Moreno. The Sugar Mill: The Socioeconomic Complex of Sugar in Cuba, 1760-1860. Translated by Cedric Belfrage, Monthly Review Press, 1976.

Gates, Henry Louis, Jr. "Utter Darkness.” 12 Years a Slave: Production Notes, Fox Searchlight Pictures, 2013. Web.

Giral, Sergio, director. El otro Francisco. Instituto Cubano del Arte e Industria Cinematográficos, 1975.

---. Rancheador. Instituto Cubano del Arte e Industria Cinematográficos, 1976.

--- Maluala. Instituto Cubano del Arte e Industria Cinematográficos, 1979.

---. Plácido. Instituto Cubano del Arte e Industria Cinematográficos, 1986.

---. María Antonia. Instituto Cubano del Arte e Industria Cinematográficos, 1991.

Giral, Sergio. Interview with Pablo Velez, "Close-Up on the Background: A Conversation with Sergio Giral, The Father of Afro-Cuban Cinema," Abernathy Magazine. Web.

González-Ripoll, Dolores, Consuelo Naranjo, Ada Ferrer, Gloria García, and Josef Opatrny. El rumor de Haití en Cuba: temor, raza y rebeldía, 1789-1844, Madrid, 2004.

Gott, Richard. Cuba: A New History, Yale University Press, 2004.

Griffith, D.W., director. Birth of a Nation. David W. Griffith Corp, 1915.

Hudson, Peter James. "The Racist Dawn of Capitalism: Unearthing the Economy of Bondage," Boston Review, March 14, 2016. Web.

James, C.L.R. A History of Negro Revolt. Independent Labour Party, 1938.

---. A History of Pan-African Revolt. Drum and Spear Press, 1969.

---. The Black Jacobins. 2nd edition, revised, 1963. Vintage, 1989.

Kaisary, Philip. "The Slave Narrative and Filmic Aesthetics: Steve McQueen, Solomon Northup, and Colonial Violence." MELUS, vol. 42, no. 2, 2017, pp. 94-114.

---. "The Haitian Revolution and Tomás Gutiérrez Alea’s La última cena." Racialized Visions: Haiti and the Hispanic Caribbean edited by Vanessa K. Valdés, SUNY University Press, forthcoming 2020.

Madden, Richard. The Island of Cuba: Its Resources, Progress, and Prospects, Considered in Relation especially to the Influence of its Prosperity on the Interests of the British West India Colonies, London, C. Gilpin, 1849.

McQueen, Steve, director. 12 Years A Slave. Fox Searchlight, 2013.

Mitchell, Margaret. Gone with the Wind. Macmillan, 1936.
Pérez, Louis A. Jr. To Die in Cuba: Suicide and Society. University of North Carolina Press, 2012.

Pontecorvo, Gillo, director. Quemada! / Burn! Alberto Grimaldi, Produzioni Europee Associati, 1969.

Sanko, Nadia Sophia. "Creolizing Carmen: Reading Performance in María Antonia, Cuba's Overlooked Carmen Adaptation." Camera Obscura, vol. 27, no. 1, 2012, pp. 157-91.

Scott, Julius S. The Common Wind: Afro-American Currents in the Age of the Haitian Revolution, Verso, 2018. 